\title{
Structure-activity relationships in hydroxy-2,3-diarylxanthone antioxidants. Fast kinetics spectroscopy as a tool to evaluate the potential for antioxidant activity in biological systems $\dagger$
}

\author{
Clementina M. M. Santos, ${ }^{a, b}$ Artur M. S. Silva, ${ }^{a}$ Paulo Filipe, ${ }^{c}$ René Santus,,${ }^{d, e}$ Larry K. Patterson,,${ }^{f, e}$ \\ Jean-Claude Mazière, ${ }^{e, g, h}{ }^{,}$José A. S. Cavaleiro ${ }^{a}$ and Patrice Morlière ${ }^{* e, g, h}$
}

Received 6th October 2010, Accepted 28th February 2011

DOI: 10.1039/c0ob00841a

\begin{abstract}
A structure-activity relationship has been established for eight hydroxy-2,3-diarylxanthones (XH) bearing hydroxy groups on the two aryl rings. One-electron oxidation by superoxide radical-anions $\left({ }^{\circ} \mathrm{O}_{2}{ }^{-}\right)$and ${ }^{\circ}$ Trp radicals as well as reaction with ${ }^{\circ} \mathrm{CCl}_{3} \mathrm{O}_{2}$ and ${ }^{\circ} \mathrm{CHCl}_{2} \mathrm{O}_{2}$ radicals demonstrates that two $\mathrm{OH}$ groups are required for efficient antioxidant reactivity in cetyltrimethylammonium bromide micelles. Hydroxy groups at the meta and para positions on either of the two phenyl rings confer enhanced reactivity, but $\mathrm{XH}$ bearing an $\mathrm{OH}$ at the para position of either phenyl ring is unreactive. While oxidation is favoured by $\mathrm{OH}$ in both meta and para positions of 2-aryl xanthone substituents, addition of a third and/or fourth $\mathrm{OH}$ enhances electron-donating capacity. In $\mathrm{Cu}^{2+}$-induced lipid peroxidation of human LDL, the lag period preceding the commencement of lipid peroxidation in the presence of $\mathrm{XH}$ bearing $\mathrm{OH}$ at meta and para positions on the 3-phenyl ring is extended to twice that observed with a comparable concentration of quercetin, a reference antioxidant. These antioxidants are also superior to quercetin in protecting human skin keratinocytes against tert-butylhydroperoxideinduced oxidative stress. While XH antioxidant activity in model biological systems is consistent with the structure-activity relationship, their response is also modulated by the localization of XH and by structural factors.
\end{abstract}

\section{Introduction}

Xanthones are natural heterocyclic compounds found in higher plants, such as lichens and fungi. ${ }^{1}$ Antiallergic, anti-inflammatory and antitumor activities have been demonstrated for this class of compounds. ${ }^{2}$ Among their most interesting properties is their strong antioxidant activity due to the presence of hydroxy groups and/or a catechol moiety at key positions. ${ }^{3}$ Oxygenated and

${ }^{a}$ University of Aveiro, Department of Chemistry \& QOPNA, 3810-193 Aveiro, Portugal

${ }^{b}$ Polytechnic Institute of Bragança, School of Agriculture, Department of Vegetal Production and Technology, 5301-855 Bragança, Portugal

'Universidade de Lisboa, Hospital de Santa Maria, Clinica Universitária de Dermatologia, 1600 Lisbon, Portugal

'Muséum National d'Histoire Naturelle, Département RDDM, F-75231 Paris, France

${ }^{e}$ INSERM ERI12, Laboratoire de Biochimie, CHU Amiens - Hôpital Nord, place Victor Pauchet, 80054 Amiens Cedex 1, France. E-mail: morliere. patrice@chu-amiens.fr; Fax: +33 3226685 93; Tel: +33 322668669

${ }^{f}$ University of Notre Dame, Radiation Laboratory, Notre Dame, Indiana 46556, USA

${ }^{g}$ INSERM, ERI12, F-80054 Amiens, France

hUniversité de Picardie Jules Verne, Faculté de Médecine et de Pharmacie, EA 4292, F-80036 Amiens, France

$\dagger$ Electronic supplementary information (ESI) available. See DOI: $10.1039 / \mathrm{c} 0$ ob00841a prenylated xanthones, extracted from mango, have been shown to be powerful antioxidants in animals and humans. ${ }^{4}$ These findings have stimulated the synthesis of polyphenolic xanthone derivatives with well-defined chemical structures. ${ }^{5}$ A preliminary study on the ability of polyhydroxylated 2,3-diarylxanthones to scavenge reactive oxygen and nitrogen species $\left({ }^{\circ} \mathrm{O}_{2}^{-}, \mathrm{HOCl}\right.$, ' $\mathrm{NO}, \mathrm{ONOO}^{-}$and singlet oxygen) has been performed using chemical methods. ${ }^{6}$ In view of encouraging results, a physical chemical study has been performed to specify the fine structural features determining the antioxidant properties of nine 2,3diarylxanthones $(\mathrm{XH})$ bearing up to 4 hydroxy groups at various sites on the two aryl rings. The first objective has been to determine by means of a fast spectroscopic technique a ranking of their comparative interactions with reactive oxygen species (ROS) in order to establish a structure-activity relationship within this class of molecules as well as to highlight the most promising molecules for further investigation in biological systems. The antioxidant and redox properties of these rather hydrophobic molecules have been assayed in a model multiphase aqueous medium which mimics the complexity of microenvironmental conditions inherent to biological structures. The present investigation has been carried out in cationic cetyltrimethylammonium bromide (CTAB) buffered $(\mathrm{pH}$ 7) micellar solutions, using pulse radiolysis to determine reaction kinetics. With this technique one may convert all primary species 
of water radiolysis into superoxide radical-anions ${ }^{7}\left({ }^{\circ} \mathrm{O}_{2}{ }^{-}\right)$, the most abundant ROS produced by cellular oxidation. ${ }^{8}$ For purposes of identification, the radicals resulting from the oxidation of $\mathrm{XH}$ by ${ }^{\circ} \mathrm{O}_{2}^{-}$, have been compared to those generated by oxidation of these 2,3-diarylxanthones with mildly oxidizing ${ }^{\circ} \mathrm{Br}_{2}{ }^{-}$radicalanions or by repair of neutral indolyl radicals ( $\left.{ }^{\circ} \mathrm{Trp}\right)$ produced via one-electron oxidation of the aromatic amino acid, tryptophan. ${ }^{9}$ In addition, the reactivity of the XH with trichloromethylperoxyl and dichloromethylperoxyl radicals has also been determined as the latter can be considered to be models of ROS derived from widely used halogenated organic compounds of environmental impact or as halogenated products of drug-metabolizing liver systems. ${ }^{10}$ Also, these may be considered as approximate models for intermediates of lipid peroxidation.

The second objective of this work has been to employ the structure-activity relationship established by physical-chemical means to understand the specificity of these XH antioxidants for control of oxidative processes in two well-established biologically relevant but structurally different model systems. These systems are: (1) human blood LDL and (2) human skin keratinocytes. Initially, we have compared the ability of the various $\mathrm{XH}$ to inhibit the $\mathrm{Cu}^{2+}$-induced lipid peroxidation of LDL. Subsequently, in cellular studies, cytotoxic effects in keratinocytes were utilized as markers of cell injury. In these measurements with keratinocytes, oxidative stress has been generated by the amphiphilic tertbutylhydroperoxide (tert-BuOOH), a stable organic hydroperoxide. In all cases, the protection afforded by XH has been compared to that of quercetin, one of the most effective natural flavonoid antioxidants in $\mathrm{Cu}^{2+}$-induced lipid peroxidation of $\mathrm{LDL}^{11,12}$ and in oxidative stress-related cytotoxic effects. ${ }^{13}$

\section{Materials and methods}

\section{Physical-chemical studies}

The hydroxylated 2,3-diarylxanthones (XH) (Fig. 1) were synthesized as described by Santos et al. ${ }^{5}$ (see the ESI $\dagger$ ). All other chemicals were of analytical grade and were used as received from the suppliers. D,L-Tryptophan (Trp), tert-BuOOH, quercetin (Q), sodium dodecyl sulfate (SDS), Neutral Red (NR) and cetyltrimethylammonium bromide (CTAB) were purchased from Sigma (St Louis, Mo, USA). Spectroscopic grade dimethylsulfoxide (DMSO), absolute ethanol, tert-butanol, chloroform and carbon tetrachloride were supplied by Merck (Darmstad, Germany). The phosphate buffer ( $\mathrm{pH} 7$ ) was prepared in pure water obtained with a reverse osmosis system from Ser-A-Pure Co. The water from this system exhibited a resistivity of $>18{\mathrm{M} \Omega \mathrm{cm}^{-1}}^{-1}$ and a total organic content of $<10 \mathrm{ppb}$. Pure $\mathrm{N}_{2} \mathrm{O}$ and $\mathrm{O}_{2}$ were used for pulse radiolysis experiments. Absorption spectrophotometry was carried out with Uvikon 922 and Shimadzu UV-2101PC spectrophotometers.

Pulse radiolysis measurements were performed with the Notre Dame Radiation Laboratory $8 \mathrm{MeV}$ linear accelerator, which generates $5 \mathrm{~ns}$ pulses of up to $30 \mathrm{~Gy}$. In general, the doses used here were 10-15 Gy. The principles of the detection system have been previously described. ${ }^{14,15}$ A Corning $0-52$ optical filter, was placed in the analyzing light beam preceding the sample cell to remove all UV radiation at wavelengths $<350 \mathrm{~nm}$ and to avoid photolysis of the sample. Radical concentrations calculated from



Fig. 1 Chemical structures of the 2,3-diaryl-9H-xanthen-9-one (XH1-XH9; 2,3-diarylxanthones) in this study.

transient absorbance data are referenced to $(\mathrm{SCN})_{2}{ }^{-}$dosimetry. The extinction coefficient for ${ }^{\circ}(\mathrm{SCN})_{2}{ }^{-}$is $7580 \pm 60 \mathrm{M}^{-1} \mathrm{~cm}^{-1}$ at $472 \mathrm{~nm}$, and the radiolytic yield ( $G$ value) for ${ }^{\circ} \mathrm{OH}$ in $\mathrm{N}_{2} \mathrm{O}$ saturated solution has been measured as $0.63 \mu \mathrm{M} \mathrm{Gy}^{-1}$ (or $0.63 \mu \mathrm{M}$ $\left.\mathrm{kg} \mathrm{J}^{-1}\right){ }^{16}$ Solutions for pulse radiolysis were prepared in $10 \mathrm{mM}$, $\mathrm{pH} 7$, phosphate buffer solutions containing $10 \mathrm{mM} \mathrm{CTAB}$ to which were added aliquots of $0.4 \mathrm{M}$ stock solutions of $\mathrm{XH}$ in DMSO. To conserve the $\mathrm{XH}$, a microcell (optical path: $1 \mathrm{~cm}$, volume $120 \mu \mathrm{L}$ and $2 \mathrm{~mm}$ i.d.) was used for transient recording. Numerical integrations, carried out in analyses of rate data, were conducted using the Scientist software from Micromath Scientific Software.

\section{Preparation and treatment of LDL}

Serum samples were obtained from healthy volunteers. The LDL $\left(d=1.024-1.050 \mathrm{~g} \mathrm{~mL}^{-1}\right)$ was prepared by sequential ultracentrifugation. ${ }^{17}$ The LDL samples were used within 2-3 weeks of preparation. Just before experimentation, LDL was dialyzed twice for 8 and $16 \mathrm{~h}$ against 1 litre of $10 \mathrm{mM}$ phosphate buffer ( $\mathrm{pH}$ 7.4) to remove EDTA and was then diluted to a final concentration of $0.15 \mathrm{mg}$ protein $\mathrm{mL}^{-1}(300 \mathrm{nM})$. Subsequently, $150 \mu \mathrm{L}$ of $5 \mu \mathrm{M}$ solutions of $\mathrm{XH}$ or of $\mathrm{Q}$ in $10 \mathrm{mM}$ phosphate buffer were added to $800 \mu \mathrm{L}$ of the diluted LDL. Blank LDL solutions without $\mathrm{XH}$ or $\mathrm{Q}$ were also prepared. The LDL solutions loaded with $\mathrm{XH}$ or $\mathrm{Q}$ and the reference LDL solutions were then incubated at $37^{\circ} \mathrm{C}$ for $15 \mathrm{~min}$. Lipid peroxidation was initiated by adding $50 \mu \mathrm{L}$ of $100 \mu \mathrm{M}$ aqueous $\mathrm{Cu}^{2+}$ solution to produce a final concentration of $5 \mu \mathrm{M} \mathrm{Cu}^{2+}$ in the incubation medium. 
Table 1 Antioxidant properties of polyhydroxylated 2,3-diarylxanthones in CTAB micelles: molar extinction coefficient $(\varepsilon)$ of the ${ }^{\circ} \mathrm{X}$ radical formed by reaction with ${ }^{\circ} \mathrm{O}_{2}{ }^{-}$and observed pseudo-first order $\left(k_{1}\right)$ rate constants for this reaction; bimolecular reaction rate constant $\left(k_{4}\right)$ for repair of the ${ }^{\circ} \operatorname{Trp}$ neutral radical by $\mathrm{XH}$ and rate constant for the reaction of XH with the trichloromethylperoxyl $\left(k_{5}\right)$ and dichloromethylperoxyl $\left(k_{6}\right)$ radicals

\begin{tabular}{llllll}
\hline Compounds & XH3 & XH6 & XH7 & XH8 & XH9 \\
\hline$\varepsilon\left(\mathrm{M}^{-1} \mathrm{~cm}^{-1}\right)^{a}$ & $2,300(410 \mathrm{~nm})$ & $1,900(420 \mathrm{~nm})$ & $1,600(510 \mathrm{~nm})$ & $2,400(460 \mathrm{~nm})$ & $1,500(440 \mathrm{~nm})$ \\
$k_{1}\left(\mathrm{~s}^{-1}\right)^{b}$ & 760 & 420 & 730 & $4.72 \pm 0.07$ & 1250 \\
$k_{4}\left(10^{7} \mathrm{M}^{-1} \mathrm{~s}^{-1}\right)$ & $3.90 \pm 0.12$ & $4.36 \pm 0.07$ & $4.40 \pm 0.06$ & $53.6 \pm 1.7$ & $120.5 \pm 6.19$ \\
$k_{5}\left(10^{3} \mathrm{~s}^{-1}\right)^{c}$ & $54.9 \pm 1.8$ & $55.2 \pm 1.6$ & $56.6 \pm 2.0$ & $15.8 \pm 0.8$ \\
$k_{6}\left(10^{3} \mathrm{~s}^{-1}\right)^{d}$ & $13.9 \pm 2.2$ & $14.8 \pm 1.7$ & $14.5 \pm 0.7$ & $22.3 \pm 0.6$
\end{tabular}

${ }^{a}$ At wavelength given in parentheses. ${ }^{b} k_{1}$ was calculated using eqn (3), the concentration was $200 \mu \mathrm{M} \mathrm{XH} .{ }^{c} 200 \mu \mathrm{M} \mathrm{XH}, \mathrm{dose}=14 \mathrm{~Gy} .{ }^{d} 200 \mu \mathrm{M} \mathrm{XH}$, dose $=19$ Gy.

\section{Conjugated diene determination and consumption of carotenoids}

Conjugated diene formation was monitored by measuring the increase in absorbance at $234 \mathrm{~nm}$ which was determined periodically during incubation. Changes in carotenoid concentration during LDL oxidation were also monitored by second derivative absorption spectroscopy in the range 400-550 $\mathrm{nm}$ and the amplitude of the second derivative spectrum between 489 and $516 \mathrm{~nm}$ was determined. These changes were then expressed as percentages of the initial concentration. ${ }^{17}$

\section{Cell culture and treatment}

The NCTC 2544 immortalized human skin keratinocyte cell line was purchased from ICN Flow (Fontenay sous Bois, France). Cultures were propagated in minimum essential medium with Earle's salts (EMEM) supplemented with $10 \%$ foetal calf serum

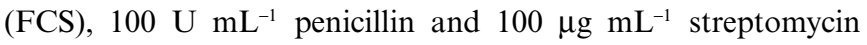
(weekly passages, 1:10 splitting ratio). Cells from trypsinized confluent monolayers were seeded at a density of 15000 cells $\mathrm{cm}^{-2}$ on plates with 24 wells of about $2 \mathrm{~cm}^{2}$ each, containing $1 \mathrm{~mL}$ of complete medium (EMEM supplemented with FCS). These were grown for 4 days to about $75 \%$ confluency. After two washings with $1 \mathrm{~mL}$ of phosphate buffer saline (PBS), cells were incubated for $1 \mathrm{~h}$ at $37^{\circ} \mathrm{C}$ with $250 \mu \mathrm{L}$ of XH in PBS at the desired concentration. Then, after addition of $5 \mathrm{mM}$ tert-BuOOH (from $0.125 \mathrm{M}$ stock solutions in PBS) and incubation for $2 \mathrm{~h}$ with the oxidant, cells were washed and further incubated for $2 \mathrm{~h}$ at $37^{\circ} \mathrm{C}$ in complete medium. After two washings with PBS, the challenged cells were submitted to the viability assay with Neutral Red (NR). The $2 \mathrm{~h}$ lag between treatment and assay was chosen to allow the initial damage to propagate but was short enough to avoid important proliferation of undamaged cells (population doubling time is about 1 day) which may obscure the effect of the oxidative stress.

\section{Neutral Red uptake assay}

The cytotoxicity of tert-BuOOH on NCTC 2544 keratinocytes, was determined by the NR uptake assay. ${ }^{12,13}$ The day before the assay, a saturated aqueous NR solution was diluted $(1: 80 \mathrm{v} / \mathrm{v})$ with complete medium and left overnight at $37{ }^{\circ} \mathrm{C}$. Just before use, this NR solution was centrifuged twice to eliminate excess NR precipitate. Challenged cells were washed and incubated with $250 \mu \mathrm{L}$ of this NR solution for $2 \mathrm{~h}$ at $37{ }^{\circ} \mathrm{C}$. Then, after 3 washings with PBS, $400 \mu \mathrm{L}$ of a $1 \%$ aqueous SDS solution were added to solubilise the cells, and absorbance was subsequently determined at $550 \mathrm{~nm}$ in 96 microwell plates. Data are presented as the percentage of NR uptake with respect to that of a control experiment carried out in the absence of oxidant. The data are the mean $\pm \mathrm{SD}$ of at least three independent experiments, each performed in triplicate.

\section{Results and discussion}

\section{Fast kinetics spectroscopy results}

One-electron oxidation of $\mathrm{XH}$ by ${ }^{\cdot} \mathrm{O}_{2}^{-}$radical-anions: characterization of transient absorption spectra of the semi-oxidized XH and reaction kinetics. ${ }^{\prime} \mathrm{O}_{2}^{-}$may be chosen as a good elementary model for ROS in which to evaluate the potential antioxidant activity of XH. In $\mathrm{O}_{2}$-saturated $10 \mathrm{mM} \mathrm{CTAB}$ micellar solutions containing $0.1 \mathrm{M}$ formate ions, all the primary radical species of water radiolysis $\left(\mathrm{e}_{\mathrm{aq}}, \mathrm{H}^{\cdot},{ }^{\circ} \mathrm{OH}\right)$ are converted into ${ }^{\circ} \mathrm{O}_{2}{ }^{-}$with $G\left({ }^{\cdot} \mathrm{O}_{2}^{-}\right)=0.65 \mu \mathrm{M} \mathrm{Gy}{ }^{-1} \cdot{ }^{18}$ These ${ }^{\cdot} \mathrm{O}_{2}^{-}$are found to readily react with $\mathrm{XH} 3, \mathrm{XH} 6, \mathrm{XH} 7, \mathrm{XH} 8$ and $\mathrm{XH} 9$, producing the transient absorption spectra shown in Fig. 2A,B.

The $\mathrm{XH} 2$ derivative with its single $\mathrm{OH}$ substitution on the 2phenyl ring sluggishly reacts with ${ }^{\circ} \mathrm{O}_{2}{ }^{-}$(Fig. 3). However, $\mathrm{XH} 4$ bearing one $\mathrm{OH}$ group in the para position of the 3-phenyl ring, as well as $\mathrm{XH} 5$ bearing an $\mathrm{OH}$ group in the para position of each phenolic ring, does not react with ${ }^{\circ} \mathrm{O}_{2}{ }^{-}$. The $\mathrm{XH} 1-$ the lead structure lacking phenolic hydrogen - is also unreactive. By analogy with other polyphenols, ${ }^{19}$ it is concluded that the electron donating activity of these hydroxy groups probably governs the kinetics of the reaction:

$$
\mathrm{O}^{-}{ }^{-}+\mathrm{XH} \rightarrow{ }^{\cdot} \mathrm{X}+\mathrm{HO}_{2}^{-}
$$

The one-electron oxidation of the reactive $\mathrm{XH}$ by ${ }^{\circ} \mathrm{O}_{2}{ }^{-}$occurs in these measurements on a $5 \mathrm{~ms}$ time scale (Fig. 3) and yields rate constants in the range $k_{1}=0.4-1.3 \times 10^{3} \mathrm{M}^{-1} \mathrm{~s}^{-1}$ (see below and Table 1 ). The ${ }^{\cdot} \mathrm{X}$ radicals thus formed are rather stable since no appreciable decay is observed on a $50 \mathrm{~ms}$ time scale (data not shown).

The assignment of transient spectra in Fig. 2A,B to the products of one-electron oxidation of $\mathrm{XH}$ by ${ }^{\circ} \mathrm{O}_{2}{ }^{-}$was corroborated by pulse radiolysis in $\mathrm{N}_{2} \mathrm{O}$-saturated $\mathrm{CTAB}$ solutions containing $0.1 \mathrm{M}$ $\mathrm{KBr}$. Here $\mathrm{e}_{\mathrm{aq}}$ and ${ }^{\circ} \mathrm{OH}$ radicals are converted into ${ }^{\circ} \mathrm{Br}_{2}{ }^{-}(G=$ $\left.0.64 \mu \mathrm{M} \mathrm{Gy}^{-1}\right){ }^{18} \mathrm{As}{ }^{\bullet} \mathrm{Br}_{2}{ }^{-}$is a mild oxidant $\left(E_{0}\left({ }^{\circ} \mathrm{Br}_{2}^{-} / 2 \mathrm{Br}^{-}\right)=1.63 \mathrm{~V}\right.$ vs. NHE), it is commonly used for the one-electron oxidation of various aromatic molecules. Here $\mathrm{XH}$ are readily oxidized via the reaction: 

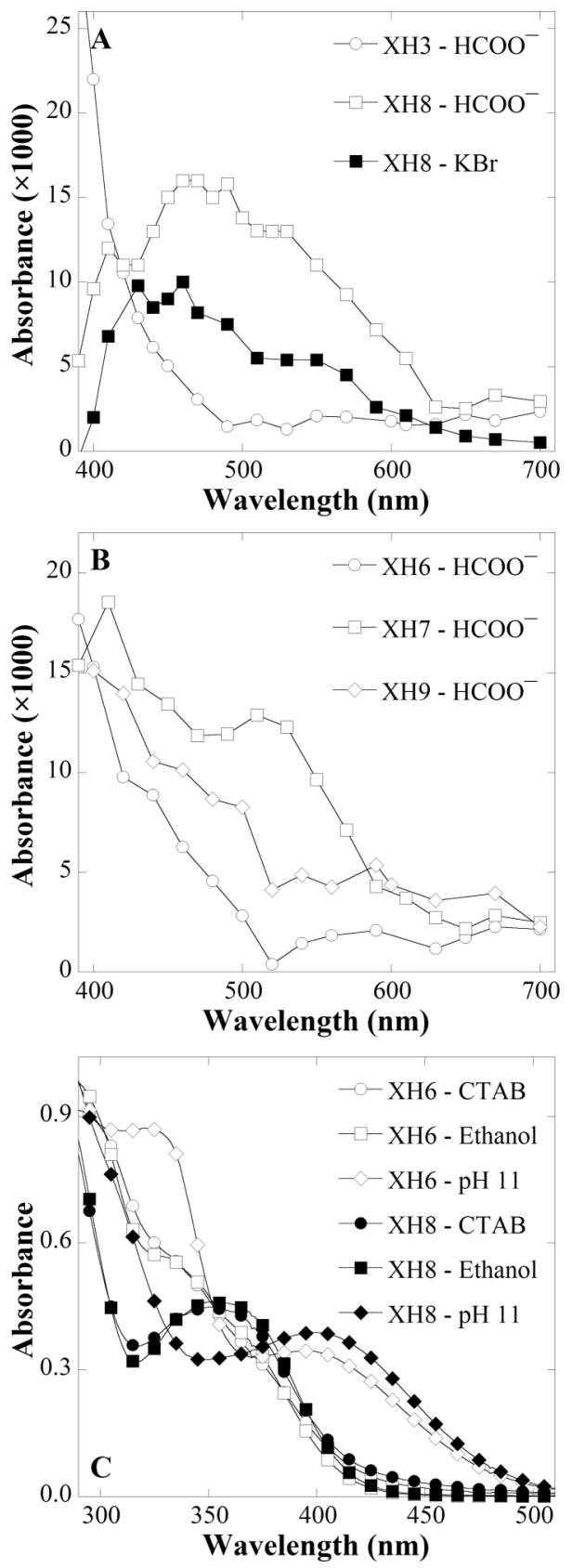

Fig. 2 A Transient absorption spectra obtained $4 \mathrm{~ms}$ after pulse radiolysis of $200 \mu \mathrm{M}$ XH3 $(\bigcirc)$ or $200 \mu \mathrm{M}$ XH8 $(\square)$ in $\mathrm{O}_{2}$-saturated, $10 \mathrm{mM}$ phosphate buffer ( $\mathrm{pH} 7$ ) containing $0.1 \mathrm{M} \mathrm{HCOO}^{-}$and $10 \mathrm{mM} \mathrm{CTAB}$, or $200 \mu \mathrm{M} \mathrm{XH8} \mathrm{( \square )} \mathrm{in} \mathrm{N}_{2} \mathrm{O}$-saturated, $10 \mathrm{mM}$ phosphate buffer $(\mathrm{pH}$ 7) containing $0.1 \mathrm{M} \mathrm{KBr}$ and $10 \mathrm{mM}$ CTAB. Doses were $11 \mathrm{~Gy}(\bigcirc, \square)$ or 13 Gy (ם). B Transient absorption spectra obtained $4 \mathrm{~ms}$ after pulse radiolysis of $200 \mu \mathrm{M} \mathrm{XH7}(\square), \mathrm{XH} 9(\diamond), \mathrm{XH} 6(\bigcirc)$ in $\mathrm{O}_{2}$-saturated, $10 \mathrm{mM}$ phosphate buffer ( $\mathrm{pH} 7$ ) containing $0.1 \mathrm{M} \mathrm{HCOO}^{-}$and $10 \mathrm{mM} \mathrm{CTAB}$. Dose was $11 \mathrm{~Gy}$. C Absorption spectra of $50 \mu \mathrm{M} \mathrm{XH6}$ and XH8 in ethanol, in $10 \mathrm{mM}$ phosphate buffer ( $\mathrm{pH} 7$ ) containing $10 \mathrm{mM} \mathrm{CTAB}$ and in $1 \mathrm{mM}$ $\mathrm{NaOH}$ in water. Optical path: $1 \mathrm{~cm}$.

$$
\cdot \mathrm{Br}_{2}^{-}+\mathrm{XH} \rightarrow \cdot \mathrm{X}+2 \mathrm{Br}^{-}+\mathrm{H}^{+}
$$

in competition with the fast ${ }^{\cdot} \mathrm{Br}_{2}{ }^{-}$dismutation reaction (rate constant: $2 k=4.3 \times 10^{9} \mathrm{M}^{-1} \mathrm{~s}^{-1}$ in buffer) which generates a transient absorption spectrum with a shape similar to that

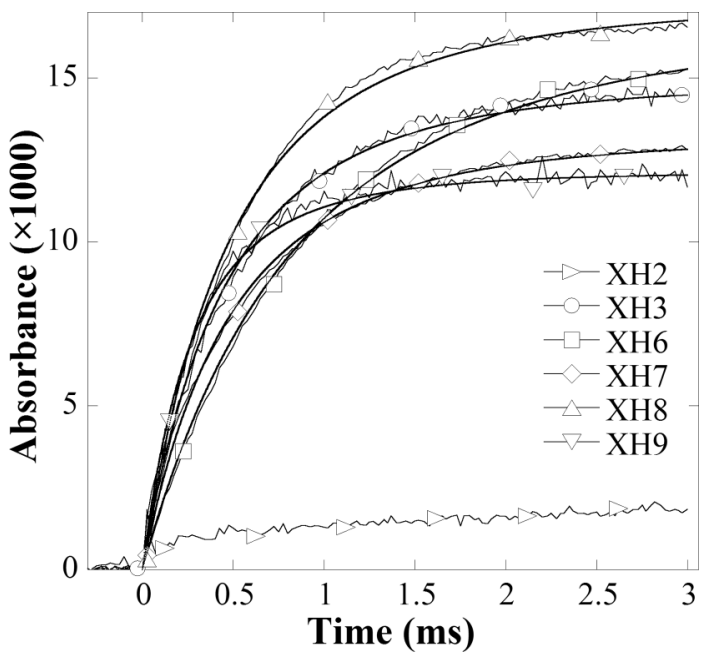

Fig. 3 Growth of ' $\mathrm{X}$ radical absorbance following pulse radiolysis of $\mathrm{O}_{2}$-saturated $10 \mathrm{mM}$ phosphate buffered solutions ( $\mathrm{pH}$ 7) containing $0.1 \mathrm{M}$ sodium formate and $10 \mathrm{mM} \mathrm{CTAB}$ in the presence of $200 \mu \mathrm{M} \mathrm{XH.}(\triangle)$ XH8 (460 nm, dose = $11 \mathrm{~Gy}),(\square)$ XH6 $(420 \mathrm{~nm}$, dose = $13 \mathrm{~Gy}),(\bigcirc)$ XH3 $(410 \mathrm{~nm}$, dose $=10 \mathrm{~Gy}),(\diamond) \mathrm{XH} 7(510 \mathrm{~nm}$, dose = $13 \mathrm{~Gy}),(\nabla) \mathrm{XH} 9$ $(440 \mathrm{~nm}$, dose $=13 \mathrm{~Gy}),(\triangleright) \mathrm{XH} 2(400 \mathrm{~nm}$, dose $=11 \mathrm{~Gy})$. Solid lines are fits of kinetics with eqn (3).

obtained by oxidation via ${ }^{\cdot} \mathrm{O}_{2}{ }^{-}$. However a lower yield is observed in Fig. $2 \mathrm{~A}$ for ${ }^{\circ} \mathrm{Br}_{2}{ }^{-}$reacting with XH8. Two factors may contribute to the higher ${ }^{\circ} \mathrm{X}$ yield obtained with ${ }^{\circ} \mathrm{O}_{2}{ }^{-}$as compared to ${ }^{\circ} \mathrm{Br}_{2}{ }^{-}$. First, while the bulk $\mathrm{pH}$ is 7 , the $\mathrm{pH}$ at the water/CTAB micelle interface is $\sim 9.5 .{ }^{20}$ This basic $\mathrm{pH}$ can shift the ionic equilibrium of ground state $\mathrm{XH}$ towards the $\mathrm{X}^{-}$species in the region of the micelle interface. For illustration, the ground state absorption spectra of $50 \mu \mathrm{M}$ XH6 and XH8 in ethanol, in $1 \mathrm{mM} \mathrm{NaOH}$ and in buffered $10 \mathrm{mM} \mathrm{CTAB}$, are shown in Fig. 2C. Due to their poor solubility in $\mathrm{pH} 7$ buffer, unstable solutions of all $\mathrm{XH}$ are obtained in this medium and are accompanied by precipitate formation, the least soluble $\mathrm{XH}$ being those with a number of $\mathrm{OH}$ groups $\leq 2$ (data not shown). In all cases, the red-shift of the longest wavelength maximum absorption of the ionized polyhydroxylated 2,3-diarylxanthones observed at $\mathrm{pH} 11$ is not observed in the $\mathrm{CTAB}$ micelles, but the broadening of the $\mathrm{XH}$ absorbance at the red edge of the absorption spectra observed for XH6 and XH8 in CTAB suggests the presence of a small concentration of ionized species. As a rule, phenolate forms of polyphenols are more oxidizable than neutral molecules. ${ }^{19}$ Secondly, the rate of ' $\mathrm{O}_{2}{ }^{-}$dismutation is several orders of magnitude slower at the basic $\mathrm{pH}$ provided by the micellar surface. ${ }^{21}$ This behavior can facilitate effective stabilization of ${ }^{\prime} \mathrm{O}_{2}{ }^{-}$by the positively charged micelles, which kinetically favors reaction (1). Under these conditions, the molar absorbance of the $\mathrm{X}$ radicals at the indicated wavelengths has been determined by pulse radiolysis (Table 1 ) assuming $G(\cdot \mathrm{X})=$ $0.65 \mu \mathrm{M} \mathrm{Gy}^{-1}$, e.g. stoichiometric reduction of ${ }^{\cdot} \mathrm{O}_{2}^{-}$by $\mathrm{XH}$ in $\mathrm{CTAB}$ micelles. As compared to those obtained for the flavonoid quercetin ${ }^{19,22}$ in similar studies, the resulting values in the visible range are rather small and are reflected in the rather weak transient absorbance as well as somewhat unsatisfactory spectral resolution obtained with ${ }^{\circ} \mathrm{Br}_{2}{ }^{-}$as the oxidizing radical. However, it must be noted that a much higher transient absorption comparable to that obtained for example with catechin is observed for $\mathrm{XH} 3$ in the UV 
range. Unfortunately, similar transient absorption measurements in the UV region cannot be performed with the other $\mathrm{XH}$ shown in Table 1 because of their noticeable absorption in the $350-420 \mathrm{~nm}$.

The rate constants $k_{1}$ given in Table 1 for the reaction of 2,3-diarylxanthones with ${ }^{\circ} \mathrm{O}_{2}{ }^{-}$have been determined using the mathematical treatment described for reaction of ${ }^{\cdot} \mathrm{O}_{2}{ }^{-}$with 3alkylpolyhydroxyflavones in CTAB micelles. ${ }^{22}$ This calculation assumes Poisson statistics for distributions of $\mathrm{XH}$ and ${ }^{\cdot} \mathrm{O}_{2}^{-}$, a critical micellar concentration of $180 \mu \mathrm{M}$ and an aggregation number $(n)=130$ for $10 \mathrm{mM}$ CTAB in $\mathrm{pH} 7$ buffer with $0.1 \mathrm{M}$ $\mathrm{HCOO}^{-}$(ref. 22). Under these conditions the CTAB micelle concentration $([\mathrm{M}])$ is found to be $75 \mu \mathrm{M}$. The fraction $f(\mathrm{i})$ of micelles with (i) XH molecules is given by $f(\mathrm{i})=\left(R^{\mathrm{i}} / \mathrm{i} !\right) \times \exp (-R)$ with $R=[\mathrm{XH}] /[\mathrm{M}]$; e.g. $\sim 95 \%$ of micelles contain at least one $\mathrm{XH}$ with $[\mathrm{XH}]=200 \mu \mathrm{M}$. With the ${ }^{\cdot} \mathrm{O}_{2}{ }^{-}$concentrations produced at doses of $10-15 \mathrm{~Gy}$, the only significant fraction of CTAB micelles containing ${ }^{\circ} \mathrm{O}_{2}{ }^{-}$is $f(1) \leq \sim 0.1$.

Under these assumptions, the production of ${ }^{\cdot} \mathrm{X}$ radicals should be:

$$
[\cdot \mathrm{X}]_{\mathrm{t}}=[\cdot \mathrm{X}]_{\infty}\left(1-\exp \left\{-R+R \exp \left(-k_{1} t\right)\right\}\right)
$$

given that every ${ }^{\bullet} \mathrm{O}_{2}{ }^{-}$which disappears corresponds to the appearance of one ${ }^{\prime} \mathrm{X}$ radical. With the caveat that there is no decay of $\mathrm{X}$ on the intermediate time scale (see above), this equation can be used to fit the kinetic traces in Fig. 3 which represent the growth of the ${ }^{\cdot} \mathrm{X}$ transient absorbance at wavelengths convenient for observation.

The rate constant $k_{1}$ is a pseudo-first order rate constant in units of reciprocal time. The rate constant $k_{1}$ represents the process of one $\mathrm{XH}$ molecule reacting with a ${ }^{\cdot} \mathrm{O}_{2}{ }^{-}$in a micelle. It thus represents the reactivity of the individual polyhydroxylated 2,3-diarylxanthones with ${ }^{\circ} \mathrm{O}_{2}^{-}$in this well defined system. With the exception of $\mathrm{XH} 6$, all other $\mathrm{XH}$ are better ${ }^{\cdot} \mathrm{O}_{2}{ }^{-}$scavengers than the 3-alkyl-3'4'5,7-tetrahydroxyflavones studied by Silva et $a .^{22}$ under similar experimental conditions. For example, the $\mathrm{XH} 9$ derivative is twice as reactive with ${ }^{\circ} \mathrm{O}_{2}{ }^{-}$as 3-decyl3'4'5,7-tetrahydroxyflavone, the most efficient 3-alkyl-3'4'5,7tetrahydroxyflavone (compare $k_{1}$ values in this work and in Table 1 of Silva et al..$^{22}$ ).

The rate constants $k_{1}$ in Table 1 demonstrate quantitatively that not only the number of $\mathrm{OH}$ groups but also their positions on the aryl rings govern the kinetics of $\mathrm{XH}$ oxidation by $\mathrm{O}_{2}{ }^{-}$. It may be seen that substitution of $\mathrm{OH}$ at both meta and para positions on either of the two phenyl rings (XH3 and XH7) leads to increased reactivity, whereas no reactivity is observed with $\mathrm{XH} 5$ bearing a single $\mathrm{OH}$ group in the para position of each phenyl ring. Interestingly, in the cases of XH6 and XH8 which bear three $\mathrm{OH}$ groups, oxidation seems again to depend on the presence of $\mathrm{OH}$ groups in both meta and para positions of one of the phenyl rings. A single para $\mathrm{OH}$ on the 3-phenyl ring appears to markedly diminish activity. This is best illustrated in the uniquely low value of $k_{1}$ for XH6, the only $\mathrm{XH}$ with three $\mathrm{OH}$ groups in Table 1 bearing such a substituent. Finally, addition of a fourth $\mathrm{OH}$ group (XH9) strongly enhances the electron-donating capacity. It should be noted that with the exception of XH6, the order of reactivity of $\mathrm{XH}$ with ${ }^{\circ} \mathrm{O}_{2}^{-}$shown here generally agrees with that determined with the NBT test. ${ }^{6}$ Clearly, the observed selectivity in - and the magnitude of - the one-electron oxidation of $\mathrm{XH}$ are influenced both by the very mild oxidant character of ${ }^{\circ} \mathrm{O}_{2}{ }^{-}\left(E_{0}\left(\mathrm{O}_{2} /{ }^{\cdot} \mathrm{O}_{2}{ }^{-}\right)=\right.$ $-330 \mathrm{mV}$ vs. NHE) and the nature of the microenvironment.

Repair of semi-oxidized tryptophan by polyhydroxylated 2,3diarylxanthones. While the potential antioxidant activity of $\mathrm{XH}$ has been addressed in terms of reactivity towards ${ }^{\circ} \mathrm{O}_{2}^{-}$it is of interest to examine potential protective action towards other important targets of oxidative reaction in biological systems, such as amino acids, free or incorporated in peptides and proteins. Tryptophan is a good model amino acid since it is one of the most oxidizable key residues of proteins. ${ }^{23,24}$ Repair of the ${ }^{\bullet}$ Trp neutral radical by polyphenols, such as flavonoids, is well documented ${ }^{25}$ and provides a reference for comparison of the potential protective action produced by different classes of antioxidants. Pulsed irradiation of buffered ( $\mathrm{pH}$ 7) $\mathrm{N}_{2} \mathrm{O}$-saturated CTAB solutions containing $0.1 \mathrm{M} \mathrm{KBr}, 1 \mathrm{mM}$ Trp and $\mathrm{XH}$ concentrations varying from 50 to $200 \mu \mathrm{M}$ leads initially to stoichiometric reaction of $\cdot \mathrm{Br}_{2}{ }^{-}$with the large excess of Trp. This oxidation reaction occurs within a few $\mu$ s following the radiolytic pulse and occurs with a rate constant of $8.6 \times 10^{8} \mathrm{M}^{-1} \mathrm{~s}^{-1}{ }^{25}$ The neutral ${ }^{\circ} \operatorname{Trp}$ radical $\left(\mathrm{p} K_{\mathrm{a}}=\right.$ 4.7) is produced, exhibiting its characteristic transient absorption maximum at $520 \mathrm{~nm}\left(\varepsilon=1750 \mathrm{M}^{-1} \mathrm{~cm}^{-1}\right)$ and a lower absorption in the 430-440 $\mathrm{nm}$ region $\left(\varepsilon \sim 500-600 \mathrm{M}^{-1} \mathrm{~cm}^{-1}\right){ }^{9}$ Due to the high redox potential $\left(E_{0}\left({ }^{\circ} \operatorname{Trp}, \mathrm{H}^{+} / \operatorname{Trp}\right) \sim 1 \mathrm{~V}\right)$ of the neutral ${ }^{\bullet} \operatorname{Trp}$ radical, ${ }^{26}$ the formation of ${ }^{\bullet} \mathrm{X}$ radicals by electron transfer reaction occurs via the reaction

$$
\cdot \operatorname{Trp}+\mathrm{XH} \rightarrow \cdot \mathrm{X}+\operatorname{Trp}
$$

Reaction (4) follows pseudo-first order kinetics whenever [XH] $\gg\left[{ }^{\circ} \mathrm{Trp}\right]$. Depending on the profile of the ${ }^{\circ} \mathrm{X}$ transient absorption spectrum, this process can be monitored either through the growth of absorbance in the $430-440 \mathrm{~nm}$ region, or through the decay of -Trp radical absorbance at $520 \mathrm{~nm}$. This behavior is exemplified in Fig. 4 for XH3 and XH8.

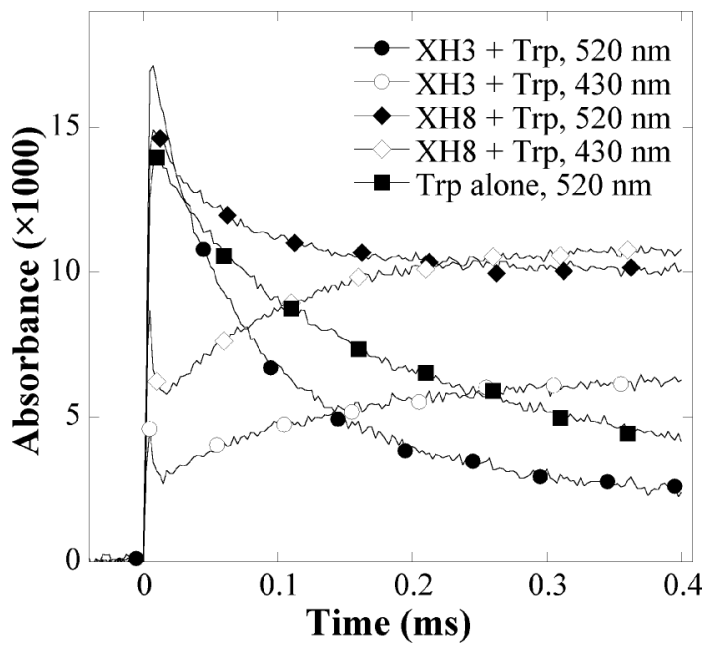

Fig. 4 Absorbance changes after pulse radiolysis of $200 \mu \mathrm{M} \mathrm{XH} 3+1 \mathrm{mM}$ $\operatorname{Trp}(\bullet, \bigcirc), 200 \mu \mathrm{M} \mathrm{XH8}+1 \mathrm{mM} \operatorname{Trp}(\diamond, \diamond)$, or $1 \mathrm{mM} \operatorname{Trp}$ alone $(\mathbf{\square})$ in $\mathrm{N}_{2} \mathrm{O}$-saturated, $10 \mathrm{mM}$ phosphate buffer $(\mathrm{pH}$ 7) containing $0.1 \mathrm{M} \mathrm{KBr}$ and $10 \mathrm{mM} \mathrm{CTAB}$. Wavelengths are $520 \mathrm{~nm}$ (closed symbols) and $430 \mathrm{~nm}$ (open symbols). Dose was $13 \mathrm{~Gy}$.

As observed with the oxidation by ${ }^{\cdot} \mathrm{O}_{2}{ }^{-}$, no significant reactivity of ${ }^{*}$ Trp toward XH1, XH2, XH4 and XH5 has been found. Rate 
constants $\left(k_{4}\right)$ in the range $\sim 4$ to $7 \times 10^{7} \mathrm{M}^{-1} \mathrm{~s}^{-1}$ have been obtained for the five other $\mathrm{XH}$ (Table 1). These reaction rate constants are similar to those obtained by Filipe et al. with quercetin, one of the most powerful flavonoid antioxidants for which a value of $\sim 6 \times 10^{7} \mathrm{M}^{-1} \mathrm{~s}^{-1}$ has been obtained. ${ }^{25}$ The relationship between the $\mathrm{XH}$ reactivity with ${ }^{\circ}$ Trp and the number of $\mathrm{OH}$ groups as well as their positions on the aryl rings diverges somewhat from that observed with ${ }^{\circ} \mathrm{O}_{2}{ }^{-}$oxidation. This is probably related to the much higher ${ }^{*}$ Trp reduction potential which thermodynamically favours reaction (4). However, again, XH9 is found to be the most oxidizable $\mathrm{XH}$ in these two systems.

An estimate of ${ }^{\circ} \mathrm{X}$ radical yield obtained via reaction (4) can be deduced from the absorbance remaining at $520 \mathrm{~nm}, 400 \mu \mathrm{s}$ after the radiolytic pulse, when all the ${ }^{\circ}$ Trp radicals have been consumed by reaction (4) (Fig. 4). This calculation can be easily performed with knowledge of the transient spectral shape (Fig. 2A,B) and molar extinction coefficients given in Table 1 . One finds that the ${ }^{\cdot} \mathrm{X}$ yield obtained from reaction (4) with $200 \mu \mathrm{M}$ XH3, XH6, XH7, XH8 or XH9 is quite similar to the ${ }^{\bullet} \operatorname{Trp}$ formation yield (e.g. $G\left({ }^{\bullet} \operatorname{Trp}\right) \sim$ $0.64 \mu \mathrm{M} \mathrm{Gy}^{-1}$ ) suggesting nearly unit electron transfer efficiency.

Deactivation of halogenated alkylperoxyl radicals by polyhydroxylated 2,3-diarylxanthones. As described above, the potential antioxidant activity of the $\mathrm{XH}$ derivatives has been demonstrated towards ${ }^{\circ} \mathrm{O}_{2}{ }^{-}$which can be produced in normal cell metabolism and towards ${ }^{\circ}$ Trp radicals that may be formed during the deleterious oxidation of essential biomolecules such as proteins and peptides. It is also of interest to elucidate $\mathrm{XH}$ antioxidant activity towards harmful radical species which can be generated in the cellular metabolism of drugs or by environmental toxicants. To extend studies into this area, we have chosen trichloromethylperoxyl $\left(\cdot \mathrm{CCl}_{3} \mathrm{O}_{2}\right)$ and dichloromethylperoxyl $\left({ }^{\cdot} \mathrm{CHCl}_{2} \mathrm{O}_{2}\right)$ as reference radicals. They have been shown to be involved in the hepatotoxicity of carbon tetrachloride ${ }^{10}$ and chloroform. These two molecules are not only good models for the general understanding of the toxicology of haloalkane anaesthetics but it may be further suggested that these haloalkylperoxyl radicals are useful models for lipid-derived peroxyl radicals. The inductive effect of the chlorine groups increases their reactivity and places their kinetics in a time range accessible to pulse radiolysis measurements.

The ${ }^{\cdot} \mathrm{CCl}_{3} \mathrm{O}_{2}$ can be conveniently produced by radiolysis according to the following sequence of reactions:

$$
\begin{aligned}
& \mathrm{H}_{2} \mathrm{O} \rightarrow \mathrm{e}_{\mathrm{aq}}, \mathrm{H}^{\cdot},{ }^{\circ} \mathrm{OH}, \mathrm{H}_{2} \mathrm{O}_{2} \\
& \mathrm{e}_{\mathrm{aq}}+\mathrm{CCl}_{4} \rightarrow{ }^{\cdot} \mathrm{CCl}_{3}+\mathrm{Cl}^{-} \\
& \cdot \mathrm{OH}+\left(\mathrm{CH}_{3}\right)_{3} \mathrm{COH} \rightarrow \text { products } \\
& \cdot \mathrm{CCl}_{3}+\mathrm{O}_{2} \rightarrow{ }^{\cdot} \mathrm{CCl}_{3} \mathrm{O}_{2}
\end{aligned}
$$

The ${ }^{\circ} \mathrm{CHCl}_{2} \mathrm{O}_{2}$ radicals can be generated by an analogous mechanism using $\mathrm{CHCl}_{3}$ instead of $\mathrm{CCl}_{4}$.

Measurements were carried out in air-saturated $\mathrm{pH} 7$ buffered aqueous solutions containing $10 \mathrm{mM}$ CTAB, $2 \mathrm{M}$ tert-butanol and $10 \mathrm{mM} \mathrm{CCl}_{4}$ (or $\mathrm{CHCl}_{3}$ ). The radiolytic yield of $\mathrm{CCl}_{3} \mathrm{O}_{2}$ and ${ }^{\circ} \mathrm{CHCl}_{2} \mathrm{O}_{2}$ radicals thus formed is $G=0.32 \mu \mathrm{M} \mathrm{Gy}{ }^{-1}$. The $\cdot \mathrm{CCl}_{3} \mathrm{O}_{2}$ radicals have a reduction potential $\geq 1.1 \mathrm{~V}$ but $<1.3 \mathrm{~V}$, slightly higher than that of ${ }^{\cdot} \operatorname{Trp}^{27}$ As a consequence, they are expected to react with $\mathrm{XH}$. Transient absorption spectra have been observed with $\mathrm{XH} 3, \mathrm{XH} 6, \mathrm{XH} 7, \mathrm{XH} 8$ and $\mathrm{XH} 9$ - the only significantly reacting $\mathrm{XH}$ - after pulse radiolysis of the above described solution to which $\mathrm{XH}$ was added to produce a concentration of $200 \mu \mathrm{M}$. Transient absorption spectra were observed under various conditions with $\mathrm{XH} 3$ and $\mathrm{XH}$ 9, chosen as representative $\mathrm{XH}$ with two or four $\mathrm{OH}$ groups. These are presented in Fig. 5A and B, respectively. Fig. 5B illustrates the similarity of the transient species obtained by reactions of $\mathrm{XH}$ with either ${ }^{\circ} \mathrm{CCl}_{3} \mathrm{O}_{2}$ or ${ }^{\cdot} \mathrm{CHCl}_{2} \mathrm{O}_{2}$ radicals. In all cases, complex time-dependent changes in the spectral shape occur (inset of Fig. 5A). The absorption spectra at early times in Fig. 5A,B are reminiscent of the $\mathrm{X}$ transient absorbance in Fig. 2A,B. However, the change here in the spectral shape over several milliseconds (inset, Fig. 5A) - especially in the near UV region - suggests the formation of several overlapping initial transient species by the reactions:

$$
\begin{gathered}
\cdot \mathrm{CCl}_{3} \mathrm{O}_{2}+\mathrm{XH} \rightarrow \text { products } \\
\cdot \mathrm{CHCl}_{2} \mathrm{O}_{2}+\mathrm{XH} \rightarrow \text { products }
\end{gathered}
$$

At least two main primary reaction paths for oxidation by - $\mathrm{CCl}_{3} \mathrm{O}_{2}$ radicals in homogenous solution have been identified in the literature (for a review, see Neta et al. ${ }^{28}$ ). Besides the one-electron oxidation at electron donating sites like those of $\mathrm{XH}$, phenolic groups can react with the concomitant formation of the hydroperoxide $\mathrm{CCl}_{3} \mathrm{O}_{2} \mathrm{H}$ and radicals from $\mathrm{XH}$ which differ from those generated by electron transfer. As adducts have been observed in Trp reaction with ${ }^{\circ} \mathrm{CCl}_{3} \mathrm{O}_{2},{ }^{29}$ analogous radical adduct(s) involving $\mathrm{XH}$ may be formed which can undergo further radical-radical and/or first order decomposition reaction(s).

The results shown in Fig. 5A,B and insets in these figures suggest that the oxidation of $\mathrm{XH}$ by both ${ }^{\circ} \mathrm{CCl}_{3} \mathrm{O}_{2}$ and ${ }^{\circ} \mathrm{CHCl}_{2} \mathrm{O}_{2}$ follows multiple pathways that may be governed by the differing characters of the various phenolic groups in the five $\mathrm{XH}$ (see Table 1).

In contrast to ${ }^{\circ} \mathrm{O}_{2}^{-}$and ${ }^{-} \mathrm{Br}_{2}{ }^{-}$, which are immediately electrostatically trapped by CTAB micelles, uncharged ${ }^{\circ} \mathrm{CCl}_{3} \mathrm{O}_{2}$ (and . $\left.\mathrm{CHCl}_{2} \mathrm{O}_{2}\right)$ radicals distribute in the aqueous $\left({ }^{\circ} \mathrm{CCl}_{3} \mathrm{O}_{2}\right)_{\text {aq }}$ and micellar $\left({ }^{\circ} \mathrm{CCl}_{3} \mathrm{O}_{2}\right)_{\mathrm{m}}$ phases according to their partition coefficient: $\left.\left[{ }^{\circ} \mathrm{CCl}_{3} \mathrm{O}_{2}\right)_{\mathrm{m}}\right] /\left[\left({ }^{\circ} \mathrm{CCl}_{3} \mathrm{O}_{2}\right)_{\mathrm{aq}}\right]=K$. However, the reaction with hydrophobic XH occurs almost exclusively in micelles. Because $K$ is unknown and the reaction rate constant for the radical-radical recombination reaction of ${ }^{\cdot} \mathrm{CCl}_{3} \mathrm{O}_{2}$ is fast $\left(k=2 \times 10^{8} \mathrm{M}^{-1} \mathrm{~s}^{-1}\right),{ }^{28}$ eqn (3) cannot be applied. ${ }^{22}$ As illustrated for XH3 and XH9 in the inset of Fig. 5B, the kinetics of initial transient absorbance growths follow an exponential rate law. In addition they are found to be first order with respect to the XH concentration in $10 \mathrm{mM} \mathrm{CTAB}$. As a consequence, the apparent rate constants, $k_{5}$ and $k_{6}$, can be determined from such kinetics providing direct comparison of the reactivity of $\mathrm{XH}$ under similar concentration and dose conditions (Table 1). The XH reactivities reported in this Table within $k_{5}$ or $k_{6}$ may be seen to be similar to one another save for $\mathrm{XH} 9$ which is markedly more reactive than the others. This order of reactivities is comparable to that found for the repair of the ${ }^{*} \operatorname{Trp}$ radical. It again somewhat disagrees with the order of reactivity with ${ }^{\circ} \mathrm{O}_{2}{ }^{-}$ 

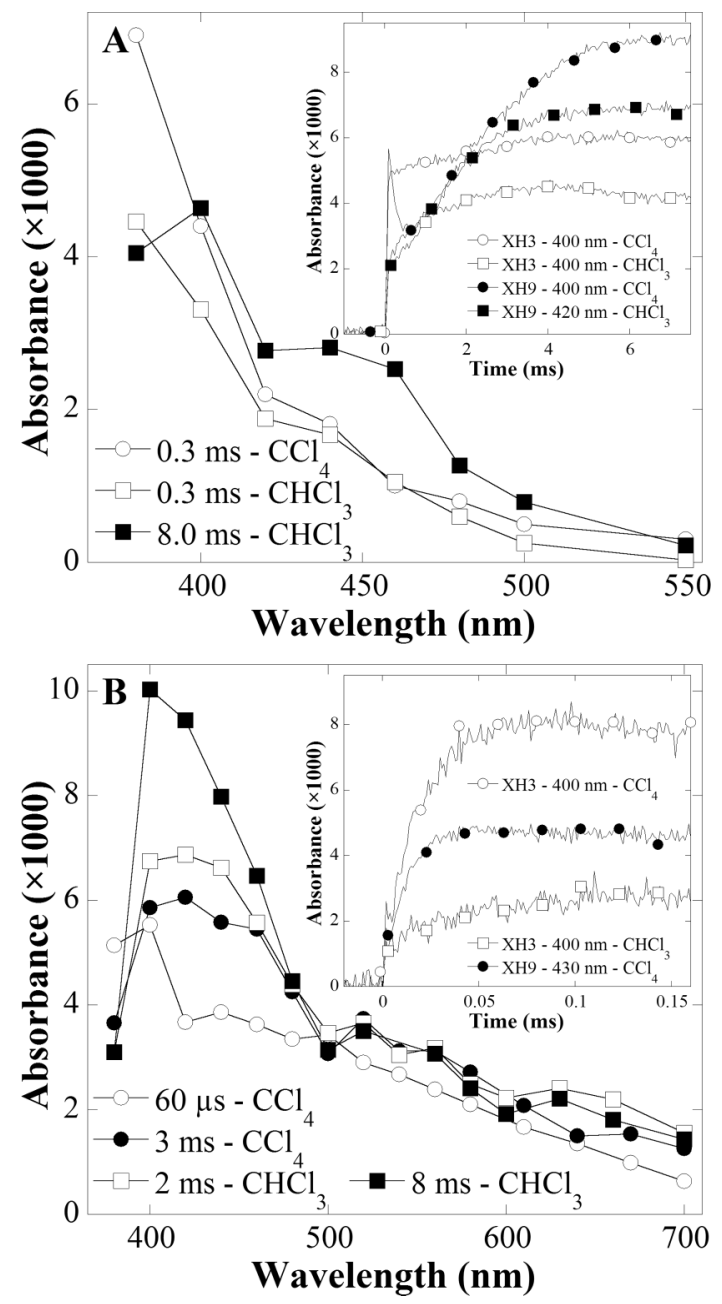

Fig. 5 A Transient absorption spectra obtained $0.3 \mathrm{~ms}$ after pulse radiolysis of $200 \mu \mathrm{M} \mathrm{XH3}$ in the presence of $10 \mathrm{mM} \mathrm{CCl}_{4}(\bigcirc)$ or after $0.3 \mathrm{~ms}(\square)$ and $8 \mathrm{~ms}(\square)$ in the presence of $10 \mathrm{mM} \mathrm{CHCl}_{3}$ in air-saturated, $10 \mathrm{mM}$ phosphate buffer $(\mathrm{pH} 7)$ containing $10 \mathrm{mM} \mathrm{CTAB}$. Doses were $13 \mathrm{~Gy}(\bigcirc)$ and $19 \mathrm{~Gy}(\square, \mathbf{\square})$. Inset: corresponding transient absorption changes on a $10 \mathrm{~ms}$ time scale after pulse radiolysis of $200 \mu \mathrm{M} \mathrm{XH} 3(\bigcirc, \square)$ or $200 \mu \mathrm{M}$ XH9 $(\mathbf{O}, \mathbf{\square})$ at wavelengths given in the inset under the same solution conditions as above. Doses were $13 \mathrm{~Gy}(\mathbf{\square}, \mathbf{\square}), 14 \mathrm{~Gy}(\mathrm{O})$ and 19 Gy $(\square)$. B Transient absorption spectra obtained $60 \mu$ s or $3 \mathrm{~ms}$ after pulse radiolysis of $200 \mu \mathrm{M} \mathrm{XH} 3$ in the presence of $10 \mathrm{mM} \mathrm{CCl}_{4}(\mathrm{O}, \mathbf{0})$ or $2 \mathrm{~ms}(\square)$ and $8 \mathrm{~ms}(\square)$ in the presence of $10 \mathrm{mM} \mathrm{CHCl}_{3}$ in air-saturated, $10 \mathrm{mM}$ phosphate buffer ( $\mathrm{pH} 7$ ) containing $10 \mathrm{mM}$ CTAB. Inset: transient absorption growth on a $200 \mu$ s time scale after pulse radiolysis of $200 \mu \mathrm{M}$ XH3 $(\bigcirc, \square)$ or $200 \mu \mathrm{M}$ XH9 $(\bullet)$ at wavelengths given in the inset under the same conditions as above. Dose was $14 \mathrm{~Gy}$ in both cases.

reflected by the $k_{1}$ values in Table 1 . This apparent discrepancy may be due, as noted above, to the low reduction potential of ${ }^{\circ} \mathrm{O}_{2}{ }^{-}$ as compared to those of the strong oxidants, ${ }^{\circ} \operatorname{Trp},{ }^{\circ} \mathrm{CHCl}_{2} \mathrm{O}_{2}$ and $\cdot \mathrm{CCl}_{3} \mathrm{O}_{2}$. An apparent overall four-fold decrease in reactivity is observed using ${ }^{\circ} \mathrm{CHCl}_{2} \mathrm{O}_{2}$ radicals in place of ${ }^{\circ} \mathrm{CCl}_{3} \mathrm{O}_{2}$, with the caveat that the pulsed irradiation dose used was somewhat lower in the ${ }^{\cdot} \mathrm{CCl}_{3} \mathrm{O}_{2}$ radicals measurements (14 Gy instead of $19 \mathrm{~Gy}$ ). This is in agreement with the general trend reported in the literature for reaction with other oxidizable substrates (see for example the data of Table 2 in Neta et al. $^{28}$ ).

\section{Biochemical and biological results}

$\mathbf{C u}^{2+}$-induced lipid peroxidation of $\mathbf{L D L}$. The initial targets for $\mathrm{Cu}^{2+}$-induced lipid peroxidation of LDL are the 8-9 Trp residues of ApoB-100. The resulting formation of indolyl radicals ( $\operatorname{Trp}$ ) triggers a radical peroxidative chain reaction in LDL lipids which are most probably located in the vicinity of the oxidized Trp residues. ${ }^{30}$ Vitamin $E$ and $\beta$-carotene and other carotenoids carried by LDL inhibit LDL lipid peroxidation until consumed but they cannot repair oxidized Trp residues. ${ }^{24}$ An induction period or lag time is thus observed between the start of the oxidation by $\mathrm{Cu}^{2+}$ ions and the appearance of characteristic lipid peroxidation products such as dienes. The duration of this induction period depends on the constitutive antioxidant content of LDL. In the four LDL preparations used for this set of experiments, the vitamin $\mathrm{E} / \mathrm{LDL}$ and $\beta$-carotene/LDL concentration ratios $(\mathrm{mol} / \mathrm{mol})$ were determined by HPLC to be $7.02 \pm 0.85$ and $0.43 \pm 0.32$, respectively. ${ }^{24}$ Fig. $6 \mathrm{~A}$ illustrates the time course of conjugated diene formation after addition of $5 \mu \mathrm{M} \mathrm{Cu}^{2+}$ to $240 \mathrm{nM}$ of native LDL in the presence or absence of $0.75 \mu \mathrm{M} \mathrm{XH}$ or Q. It may be seen that under these conditions lipid peroxidation in the absence of $\mathrm{XH}$ begins almost immediately after $\mathrm{Cu}^{2+}$ addition. The time lapse for producing $50 \%$ of the conjugated dienes obtained at plateau (CD50) is $\sim 70 \mathrm{~min}$. Addition of Q shifts the CD50 to $\sim 1.5 \mathrm{~h}$ whereas $\mathrm{XH} 1, \mathrm{XH} 2, \mathrm{XH} 4$ and $\mathrm{XH} 5$ exhibit little effect on the time course of the diene formation as compared to that of the control solution containing no added antioxidant. By contrast, the other XH derivatives strongly extend the lag period and increase the CDs to more than $2 \mathrm{~h}$; the order of antioxidant effectiveness is found to be $\mathrm{Q}<\mathrm{XH} 9<\mathrm{XH} 8<\mathrm{XH} 7<\mathrm{XH} 6<\mathrm{XH} 3$. The most potent antioxidant in this system, XH3, extends the lipid peroxidation lag period to $90 \mathrm{~min}$ compared to the only $40 \mathrm{~min}$ lag period for Q. Carotenoid consumption has been monitored under the same experimental conditions (Fig. 6B) and corroborates the order of antioxidant effectiveness for $\mathrm{XH}$, established with diene formation.

Overall, these data are consistent with the structure-activity relationships established from pulse radiolysis data. However, some observations are at variance with the chemically derived structure-activity relationship. For example, XH3 and XH6 and, to a lesser extent, $\mathrm{XH7}$, are noticeably more potent than XH8 and XH9 in LDL. The opposite trend holds for XH reactivity towards ${ }^{\circ} \mathrm{O}_{2}^{-},{ }^{-}$Trp or the peroxyl radicals, all in micellar media. On the basis of previous studies, ${ }^{22}$ the large variation in the antioxidant effectiveness may be due to differing XH locations in LDL as a result of the combination of hydrophobicity and steric factors. Owing to its four hydroxy groups, the distribution of the less hydrophobic XH9 in LDL is expected to favor location toward the surface of the water-rich outer layer constituted of phospholipids, cholesterol and ApoB-100 apolipoprotein, the later of which envelopes the core lipid particle and contributes to its solubility in plasma.

On the other hand, more hydrophobic $\mathrm{XH}$ bearing two $\mathrm{OH}$ (XH3 and $\mathrm{XH7}$ ) or three $\mathrm{OH}$ (XH6 and XH8) should favour distribution more deeply into the phospholipid layer where the labile hydrogen sites participating in peroxidative chain reactions are found. Additionally, seemingly subtle changes in structure between isomers are reflected in the activity toward LDL. XH3 and $\mathrm{XH} 7$ are isomers as are XH6 and XH8. In chemical experiments, 

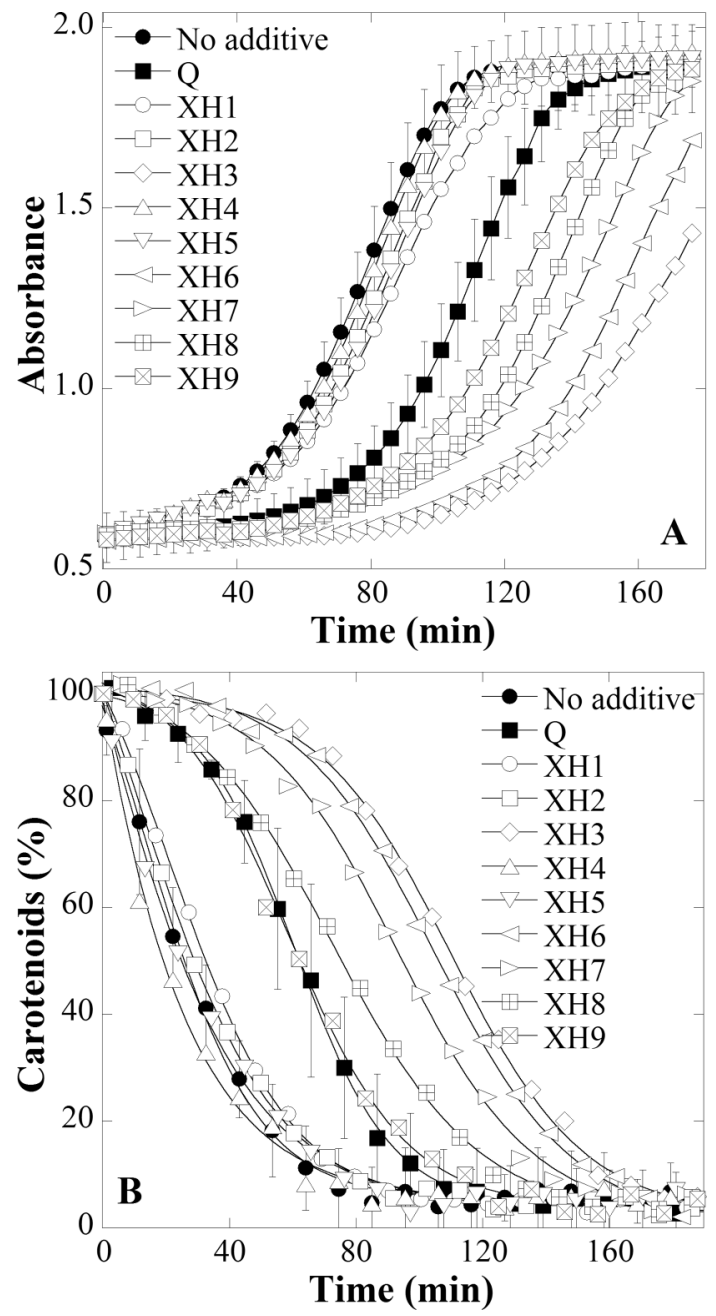

Fig. 6 A Kinetics of conjugated diene formation during LDL oxidation induced by $5 \mu \mathrm{M} \mathrm{Cu}^{2+}$. The LDL solutions in phosphate buffer ( $\mathrm{pH}$ 7.4) contain $0.12 \mathrm{mg}$ protein $\mathrm{mL}^{-1}(240 \mathrm{nM})$ and were incubated for $15 \mathrm{~min}$ at $37{ }^{\circ} \mathrm{C}$ in the presence or absence of $0.75 \mu \mathrm{M}$ of antioxidant. The absorbance was monitored at $234 \mathrm{~mm}$. Data points are the average of 4 independent experiments (4 donors). For clarity of presentation, only two kinetic traces include error bars (SD) with the results. B Kinetics of carotenoid consumption under the same conditions as those of Fig. 6A. For clarity of presentation, error bars (SD) are shown in only two of the kinetic traces.

except for ${ }^{-} \mathrm{O}_{2}^{-}$, the isomers with two phenolic groups on the 2phenyl ring appear to be overall slightly less reactive than the 3 -phenyl isomers. However in both sets of isomers the 2-phenyl isomer is markedly more protective against lipid peroxidation. These behaviours would seem best explained by selective interactions between XH structure and the LDL lipid monolayer. It may be noted that the redox metal ion-binding capacity of flavonoids such as quercetin participates in their antioxidant properties. ${ }^{31}$ Direct interaction between the XH hydroxy groups and the added $\mathrm{Cu}^{2+}$ cannot be excluded. It may contribute to the protection toward the $\mathrm{Cu}^{2+}$-induced LDL lipid peroxidation observed here, although there is a large excess of $\mathrm{Cu}^{2+}$ as compared to the $\mathrm{XH}$ concentration.

Since $\mathrm{Cu}^{2+}$-induced lipid peroxidation of LDL is a wellestablished and widely used model for testing the antioxidant capacity of molecules, comparison of the antioxidant potential of $\mathrm{XH}$ with that of other reference antioxidants can be derived. From the literature one may identify a class of antioxidants of therapeutic interest. Recently attention has focused on edavarone (3-methyl-1-phenyl-2-pyrazoline-5-one), which is active in its phenolic tautomeric form. ${ }^{32,33}$ The latter has been recently authorized in Japan for the treatment of stroke under the name Radicut ${ }^{\circledR}$. The publications cited suggest that the antioxidant capacity of this molecule is an important factor in its activity. The superiority of $\mathrm{XH}$ derivatives over edavarone can be demonstrated by an assessment of its antioxidant capacity, which was carried out with the $\mathrm{Cu}^{2+}$-induced human LDL oxidation model..$^{33}$ It may be noted that with reference to the antioxidant capacity of the $\mathrm{XH}$ - measured as the lag time for the beginning of LDL oxidation at equivalent ratios of [XH9]/[LDL] and [edavarone]/[LDL] - the activity of the "less" powerful XH9 exceeds that of edavarone (compare data from Fig. 6A and from Fig. 1 in Yoshida et $\left.a .^{33}\right)$.

tert-BuOOH-induced oxidative stress by XH in NCTC 2544 keratinocytes. In view of the findings presented above, it is of interest to extend the assessment of potential $\mathrm{XH}$ antioxidant activity to a more complex biological system than that presented by plasma LDL. Because there are numerous studies on skin cell disorders induced by various agents of oxidative and photo-oxidative stress, human skin keratinocytes have been chosen for further consideration. ${ }^{17}$ In addition to membrane lipid peroxidation, ROS have been shown to react in all skin cell compartments and with most cell structures. ${ }^{34}$ Because lipid peroxidation is the process most relevant to radical-induced skin damage, tert-BuOOH, a membrane-permeable oxidant has been selected as it acts as a source of oxygen radicals which mimic those encountered in lipid peroxidation. ${ }^{35}$ Given the large variety of cellular targets for tert$\mathrm{BuOOH}$ reported in the literature, cell death has been chosen as an overall marker of tert-BuOOH oxidative stress. ${ }^{17}$ The uptake of $\mathrm{NR}$, a lysosomotropic dye retained by intact lysosomes, was used to assess the viability of the NCTC 2544 keratinocytes subjected to the cytotoxic effects of tert-BuOOH in the absence or in the presence of the nine $\mathrm{XH}$ antioxidants.

Fig. 7 demonstrates the strong cytotoxicity of $5 \mathrm{mM}$ tertBuOOH towards NCTC 2544 keratinocytes after a $2 \mathrm{~h}$ incubation at $37^{\circ} \mathrm{C}$ in PBS in the absence of XH. After the initial damage had propagated for $2 \mathrm{~h}$ (see "Materials and methods"), less than $20 \%$ of cells recovered from injury. Addition of $5 \mu \mathrm{M}$ XH1, XH2, XH4 or XH5 - the 2,3-diarylxanthones shown to be ineffective in the other systems - provided no protection to the cells. By contrast, addition of only $0.5 \mu \mathrm{M}$ XH9, XH8, XH7 and XH6 provided some protection to the keratinocytes against the tert-BuOOH-induced oxidative stress with $\mathrm{XH} 9$ being the most protective. Little if any protection was observed with $0.5 \mu \mathrm{M}$ Q or XH3, the most effective against LDL oxidation. However, in the presence of $5 \mu \mathrm{M}$ of XH9, XH8, XH7, XH6, XH3 and Q, most cells survived. Consistent with the physico-chemical studies, the greater the number of $\mathrm{XH}$ hydroxy groups, the more effective the protection is found to be. Perhaps with the exception of XH3 which, nevertheless, is as effective as Q, the superior protection brought to a living tissue by polyhydroxylated 2,3-diarylxanthones is clearly demonstrated in these measurements. 


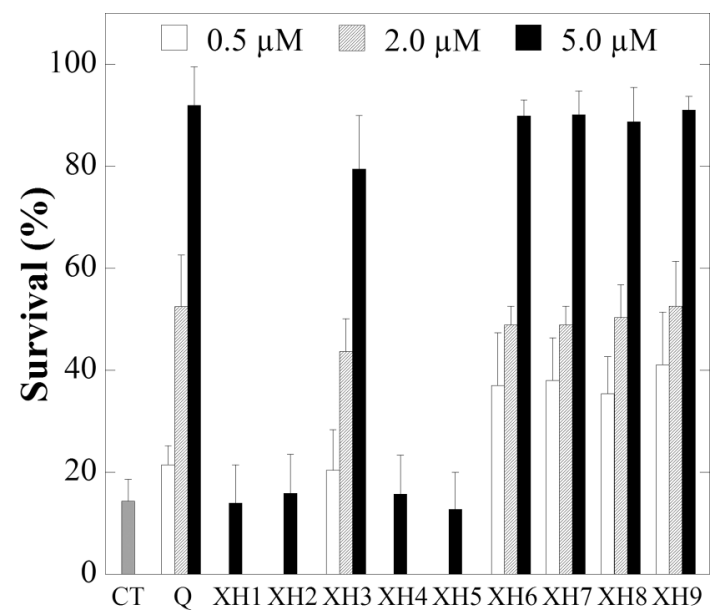

Fig. 7 Effect of 2,3-diarylxanthones and quercetin on the survival of human NCTC 2544 keratinocytes subjected to the oxidative stress generated by $5 \mathrm{mM}$ tert-BuOOH for $2 \mathrm{~h}$ at $37{ }^{\circ} \mathrm{C}$. The cells were incubated in PBS in the absence (CT) or in the presence of antioxidant at the concentrations indicated on the figure. The data are the mean \pm $\mathrm{SD}$ of at least three independent experiments, each performed in triplicate. The Neutral Red viability test was carried out according to the recommendations of the "Commission Directive 2000/33/EC" published with the Journal of the European Community of 8/6/2000: L136/90-L/07. DMSO at concentrations up to $0.1 \%$ associated with antioxidant dilution had no effect on the control.

\section{Conclusions}

Polyhydroxylated 2,3-diarylxanthones with at least two hydroxy groups in para and meta positions on the phenyl substituents of the xanthone ring are effective oxy-radical scavengers in aqueous micellar systems. Their powerful antioxidant activity can be extended to more complex biological media or cultured cells undergoing oxidative stress. The structure-activity relationship established via pulse radiolysis experiments generally applies to the biological systems studied. However, the site of $\mathrm{XH}$ localization, coupled to structural considerations, appears to be a determining factor which modulates their anti-oxidative activities in these more complex environments. In summary, this study provides a fundamental basis for understanding the powerful antioxidant potential in animals and humans of natural xanthones. These natural products may be readily extracted from mango. ${ }^{4}$ As oxidative stress is now recognized as an important component of many pathologies, the polyhydroxylated 2,3-diarylxanthones may be an interesting class of molecules for future biomedical investigations. ${ }^{36}$

\section{Acknowledgements}

This is Document No. NDLR-4864 from the Notre Dame Radiation Laboratory which is supported by the Office of Basic Energy Sciences at the United States Department of Energy. This work was supported by the Franco-Portuguese exchange programs GRICES-INSERM 2005-2006 and Pessoa 07958NF. P. Filipe thanks the "Sociedade Portugesa de Dermatologia e Venerologia" for a travel grant. Thanks are due to the University of Aveiro, "Fundação para a Ciência e a Tecnologia" and
FEDER for funding the Organic Chemistry Research Unit. Clementina M. M. Santos thanks the Calouste Gulbenkian Foundation for the award of a short period research grant (proc 87872).

\section{References}

1 L. M. Vieira and A. Kijjoa, Curr. Med. Chem., 2005, 12, 24132446.

2 M. M. Pinto, M. E. Sousa and M. S. Nascimento, Curr. Med. Chem., 2005, 12, 2517-2538.

3 A. E. Hay, M. C. Aumond, S. Mallet, V. Dumontet, M. Litaudon, D. Rondeau and P. Richomme, J. Nat. Prod., 2004, 67, 707709.

4 A. J. N. Sellès, H. T. V. Castro, J. Agüero-Agüero, J. González-González, F. Naddeo, F. de Simone and L. Rastelli, J. Agric. Food Chem., 2002, 50, 762-766.

5 C. M. M. Santos, A. M. S. Silva and J. A. S. Cavaleiro, Eur. J. Org. Chem., 2009, 16, 2642-2660.

6 C. M. M. Santos, M. Freitas, D. Ribeiro, A. Gomes, A. M. S. Silva, J. A. S. Cavaleiro and E. Fernandes, Bioorg. Med. Chem., 2010, 18, 6776-6784.

7 D. Klug, J. Rabani and I. Fridovich, J. Biol. Chem., 1972, 247, 48394842.

8 B. Halliwell and J. M. C. Gutteridge, Free Radicals in Biology and Medicine, 2nd edn, Clarendon Press, Oxford, 1989.

9 J. L. Redpath, R. Santus, J. Ovadia and L. I. Grossweiner, Int. J. Radiat. Biol., 1975, 27, 201-204.

10 T. F. Slater, K. H. Cheeseman and K. U. Ingold, Philos. Trans. R. Soc. London, Ser. B, 1985, 311, 633-645.

11 E. Cadenas and L. Packer, Handbook of Antioxidants, Marcel Dekker, New York, 1996.

12 P. Filipe, A. M. Silva, P. Morlière, C. M. Brito, L. K. Patterson, G. L. Hug, J. N. Silva, J. A. Cavaleiro, J.-C. Mazière, J. P. Freitas and R. Santus, Biochem. Pharmacol., 2004, 67, 2207-2218.

13 P. Filipe, J. N. Silva, J. Haigle, J. P. Freitas, A. Fernandes, R. Santus and P. Morlière, Photochem. Photobiol. Sci., 2005, 4, 420428.

14 L. K. Patterson and J. A. Lilie, Int. J. Radiat. Phys. Chem., 1974, 6, 129-141.

15 G. L. Hug, Y. Wang, C. Schoneich, P. Y. Jiang and R. W. Fessenden, Radiat. Phys. Chem., 1999, 54, 559-566.

16 R. H. Schuler, L. K. Patterson and E. Janata, J. Phys. Chem., 1980, 84, 2088-2089.

17 P. Filipe, A. M. Silva, R. S. Seixas, D. C. Pinto, A. Santos, L. K. Patterson, J. N. Silva, J. A. Cavaleiro, J. P. Freitas, J. C. Maziere, R. Santus and P. Morliere, Biochem. Pharmacol., 2009, 77, 957964.

18 G. V. Buxton, C. L. Greenstock, W. P. Helman and A. B. Ross, J. Phys. Chem. Ref. Data, 1988, 17, 513-886.

19 S. V. Jovanovic, S. Steenken, M. G. Simic and Y. Hara, in Flavonoids in Health and Disease, ed. C. Rice-Evans and L. Packer, Marcel Dekker, New York, 1998, pp. 137-161.

20 M. S. Fernandez and P. Fromherz, J. Phys. Chem., 1977, 81, 17551761.

21 Farhataziz and A. B. Ross, Natl. Stand. Ref. Data Ser. Natl. Bur. Stand. (U.S.), 1977, 59, 83

22 A. M. S. Silva, P. Filipe, R. S. G. R. Seixas, D. C. G. A. Pinto, L. K. Patterson, G. L. Hug, J. A. S. Cavaleiro, J.-C. Mazière, R. Santus and P. Morlière, J. Phys. Chem. B, 2008, 112, 11456-11461.

23 K. J. Davies, J. Biol. Chem., 1987, 262, 9895-9901.

24 A. Boullier, J.-C. Mazière, P. Filipe, L. K. Patterson, D. M. Bartels, G. L. Hug, J. P. Freitas, R. Santus and P. Morlière, Biochemistry, 2007, 46, 5226-5237.

25 P. Filipe, P. Morlière, L. K. Patterson, G. L. Hug, J.-C. Mazière, C. Mazière, J. P. Freitas, A. Fernandes and R. Santus, Biochim. Biophys. Acta, Gen. Subj., 2002, 1572, 150-162.

26 P. Wardman, J. Phys. Chem. Ref. Data, 1989, 18, 16371755.

27 K. D. Asmus, R. V. Bensasson, J. L. Bernier, R. Houssin and E. J. Land, Biochem. J., 1996, 315, 625-629.

28 P. Neta, R. E. Huie and A. B. Ross, J. Phys. Chem. Ref. Data, 1990, 19, 413-513. 
29 J. E. Packer, J. S. Mahood, R. L. Willson and B. S. Wolfenden, Int. J. Radiat. Biol., 1981, 39, 135-141.

30 A. Giessauf, E. Steiner and H. Esterbauer, Biochim. Biophys. Acta, Lipids Lipid Metab., 1995, 1256, 221-232.

31 C. A. Rice-Evans, N. J. Miller and G. Paganga, Free Radical Biol. Med., 1996, 20, 933-956.

32 T. Watanabe, M. Tahara and S. Todo, Cardiovascular Therapeutics, 2008, 26, 101-114.
33 H. Yoshida, K. Sasaki, Y. Namiki, N. Sato and N. Tada, Atherosclerosis, 2005, 179, 97-102.

34 D. R. Bickers and M. Athar, J. Invest. Dermatol., 2006, 126, 2565-2575.

35 A. Iannone, A. Marconi, G. Zambruno, A. Giannetti, V. Vannini and A. Tomasi, J. Invest. Dermatol., 1993, 101, 59-63.

36 R. Santus, A. M. S. Silva, C. M. M. Santos, J. A. S. Cavaleiro, P. Filipe, J.-C. Mazière and P. Morlière, Portugal Pat., 20101000024822, 2010. 